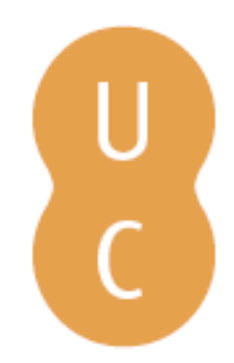

\title{
nommalina
}

\section{Animal philanthropia in the Convivium Septem Sapientium}

Autor(es): $\quad$ Newmyer, Stephen T.

Publicado por: Imprensa da Universidade de Coimbra; Centro de Estudos Clássicos e Humanísticos

URL

persistente: URI:http://hdl.handle.net/10316.2/32039

DOI: $\quad$ DOI:http://dx.doi.org/10.14195/978-989-8281-17-3_45

Accessed : $\quad$ 26-Apr-2023 11:55:33

A navegação consulta e descarregamento dos títulos inseridos nas Bibliotecas Digitais UC Digitalis, UC Pombalina e UC Impactum, pressupõem a aceitação plena e sem reservas dos Termos e Condições de Uso destas Bibliotecas Digitais, disponíveis em https://digitalis.uc.pt/pt-pt/termos.

Conforme exposto nos referidos Termos e Condições de Uso, o descarregamento de títulos de acesso restrito requer uma licença válida de autorização devendo o utilizador aceder ao(s) documento(s) a partir de um endereço de IP da instituição detentora da supramencionada licença.

Ao utilizador é apenas permitido o descarregamento para uso pessoal, pelo que o emprego do(s) título(s) descarregado(s) para outro fim, designadamente comercial, carece de autorização do respetivo autor ou editor da obra.

Na medida em que todas as obras da UC Digitalis se encontram protegidas pelo Código do Direito de Autor e Direitos Conexos e demais legislação aplicável, toda a cópia, parcial ou total, deste documento, nos casos em que é legalmente admitida, deverá conter ou fazer-se acompanhar por este aviso.

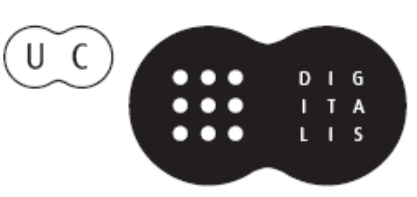




\section{Symposion and Philanthropia in Plutarch}

\section{José Ribeiro Ferreira, Delfim Leão Manuel Troster e Paula Barata Dias (eds.)}

IMPRENSA DA UNIVERSIDADE DE COIMBRA 


\title{
ANimal PHILANTHRopla IN THE ConVIVIUM SEPTEM SAPIENTIUM
}

\author{
Stephen T. Newmyer \\ Duquesne University, Pittsburgh
}

\begin{abstract}
The Convivium Septem Sapientium contains a series of references to human-animal relationships which, when read in the order of their appearance, move from a position in which animals are seen as subservient to humans to one in which animals are presumed to be capable of morallysignificant behavior, illustrated in the rescue of the singer Arion by dolphins. Plutarch's references to animals in the dialogue closely mirror his pronouncements on animal intellect and behavior in his animal-related treatises. Viewed in the light of the civilized and elevated debates that constitute the subject manner of the Convivium, the references to animals potentially capable of rational and ethical behavior add a thought-provoking parallel narrative to the dialogue.
\end{abstract}

While nineteenth-century scholarship on the Convivium Septem Sapientium concentrated heavily on questions relating to its authorship and its faithfulness to history ${ }^{1}$, scholars in recent decades have begun to examine the intellectual content of the work, giving particular attention to its political and religious themes ${ }^{2}$. Although some have called attention to the extended retelling of the famous anecdote of Arion's rescue by dolphins (160E-162B) and to the other dolphin stories that follow, the discussions of dolphins form in fact the culmination of a surprising number of references in the treatise to various aspects of the human-animal relationship. These references, which constitute a sort of "parallel narrative" in the treatise, exhibit a progression of thought, leading from situations in which humans exert dominance over animals, in sacrifice, through fables in which potential intellectual endowments in animals are referenced, and concluding with human-animal interactions of a sort that suggests rationality and moral agency in animals, manifested in particular in striking examples of $\varphi \imath \lambda \alpha v \theta \rho \omega \pi i$ in in animals that Plutarch details in the rescue of Arion and in his subsequent dolphin stories.

While it would be an exaggeration to claim that the sometimes fleeting allusions to animals in the Convivium constitute more than a secondary theme, their arrangement in the treatise clearly portrays human-animal interactions in an increasingly complex light, as Plutarch gradually draws animals closer to human beings in their intellectual capacities and finally hints at the possibility of an ethical relationship between species, when he depicts animals displaying concern for and kindness toward humans. The present study traces the development of this animal theme in the Convivium, giving particular attention

${ }^{1}$ U. von Wilamowitz-Moellendorff, 1890, p. 196, for example, criticizes Plutarch for an inability to write in a historically convincing manner, while G. HAUck, 1893, pp. 1-26, defends Plutarch's authorship on stylistic grounds and on the similarity of ideas presented in the treatise to those seen elsewhere in Plutarch, including his conviction that animals have a share of rationality, a view developed in his animal-related treatises.

${ }^{2}$ Studies that emphasize the political and religious themes prominent in the Convivium include G. J. D. Aalders, 1977; J. M. Mossman, 1977; and L. Van der Stockt, 2005. 
to the order in which references to human-animal relations are presented, and will suggest that earlier manifestations of the theme both prepare the way for the portrait of animal $\varphi \imath \lambda \alpha v \theta \rho \omega \pi i ́ \alpha$ in the latter portions of the dialogue and mirror Plutarch's pronouncements in his animal-related treatises.

The participation in the Convivium of the legendary fabulist Aesop, who was not reckoned among the Seven Sages in any ancient enumeration, greatly facilitates the introduction of animal themes into the dialogue, as he poses riddles, replies to questions, and is teased by the other interlocutors ${ }^{3}$. His function in the dialogue has been the subject of some speculation. In his annotated edition of the work, Jean Defradas notes that the portrait of Aesop offered in the Convivium is in line with those of Herodotus and Aristotle in emphasizing his "sagesse pratique", while Judith Mossman, in her study, "Plutarch's Dinner of the Seven Wise Men and Its Place in Symposion Literature," concludes that his participation allows the dialogue to "... tend toward a lighter tone" , and George Harrison, in his study, "Problems with the Genre of Problems: Plutarch's Literary Innovations," admits that Aesop's presence at an evening full of riddles should "seem appropriate, not superfluous," although he does not elaborate on his observation ${ }^{6}$. It can be argued, however, that Aesop's presence in the dialogue is rather more functional and integral than incidental or merely comical, since many of the more casual and passing references to animals in the earlier chapters of the work involve him, while the more substantial discussions of animal themes toward the end of the work are introduced by or commented on by members of the Seven.

Aesop does not figure in the dialogue's first anecdote involving animals $(146 \mathrm{~F})$, in which Thales recounts that on one occasion a sacrificial animal

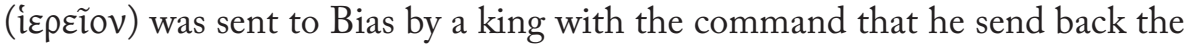
best and worst parts of the animal. Bias sent the tongue and thereby earned a reputation for cleverness. It is significant that animals make their first appearance in the work in that role, as sacrificial victims, that was reckoned most proper to them and essential to the functioning of the ancient state. Moreover, the anecdote reminds the reader of a fundamental assumption that underlay much of classical speculation on human-animal relations, namely, that humans are different from and superior to other species ${ }^{7}$. In her recent study "Beastly Spectacle in the Ancient Mediterranean World," Jo-Ann Shelton observes, "Sacrifice was a practice that emphasized the possibility of communication between humans and gods, while, at the same time, it

${ }^{3}$ Plu., Quaest. conviv. 614A-B, comments on the pedagogical, ethical and philosophical usefulness of riddles, stories and anecdotal material, the sorts of contributions that Aesop naturally makes, to convivial discourse.

${ }^{4}$ J. Defradas, 1954, p. 23.

5 J. M. Mossman, 1997, p. 124.

${ }^{6}$ G. W. M. Harrison, 2000, p. 196.

${ }^{7}$ On ancient attitudes toward the superiority of human beings to other animal species, see R. Sorabji, 1993, pp. 1-16 and 122-57; G. Steiner, 2005, pp. 1-92 and 223-51; and S. T. Newmyer, 2006, pp. 1-65. 
underscored the distinction between humans and animals" ${ }^{8}$. In Plutarch's first anecdote, animal sacrifice appears as part of a game, but the assumption of human domination and animal subjugation is evident.

In the second appearance of an animal in the treatise (149C-E), the distinction between human and animal is blurred. A young herdsman brings in a piece of leather containing a creature whose neck and arms are human but the rest of whose body is that of a horse. Although the term is not used in the text, the creature is obviously a centaur. The character Niloxenus turns away in pious horror, but Thales makes light of the portent. This peculiar incident has intrigued scholars. Defradas speculates that it may be intended as a presentiment of the spirit that infuses the later dolphin anecdotes",

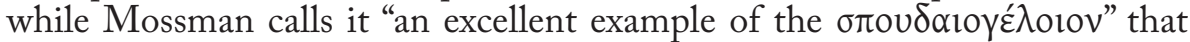
is characteristic of symposium literature ${ }^{10}$. When one recalls, however, that at least some centaurs, including Pholus and in particular Chiron, teacher of heroes and scholar of medicine, were exceptions to the rule that their kind were violent and uncivilized, one glimpses the ambivalent nature of the ancient attitude toward this creature that straddles two worlds, joining the wildness of the animal with the intellect of the human.

Plutarch effects a transition from the bizarre tale of the centaur to the series of fables involving Aesop, first mentioned as present at the banquet at $150 \mathrm{~A}$, by continuing his exploration of creatures that are, as Judith Mossman puts it, "half-and-half things" 11 . He portrays Aesop as alluding in a fable to the bastard status of Thrasybulus' son Alexidemus, who refuses to dine with the others since he feels that his dignity as the son of Thrasybulus has been slighted. Aesop recounts a tale in which a mule acts like a horse when he sees his image in a river and is impressed with his own size and handsome

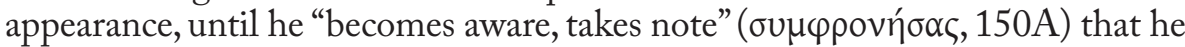
is the offspring of an ass and abandons his conceit. While it would be unwise to press the vocabulary of fables too closely, it is interesting to note that in each of Aesop's contributions, we find technical terms or illustrative examples frequently employed in ancient philosophical discussions of animal mentality.

Aristotle devoted considerable attention to the question of the content of animal intellect in relation to its human counterpart. At Nicomachean Ethics

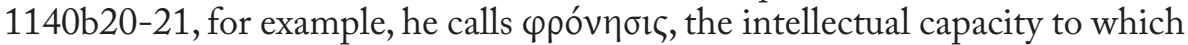
Aesop alludes in the above anecdote, a sort of "practical wisdom" that entails "a truth-attaining rational quality that concerns things good for human beings" 12 . This definition suggests that here at least he denies practical wisdom to nonhumans. At Metaphysics 980b22, however, he declares that animals possessing memory are $\varphi \rho \circ v \iota \mu \omega ́ \tau \varepsilon \rho \alpha$, "wiser, more intelligent," than other animals. In

\footnotetext{
${ }^{8}$ J.-A. Shelton, 2007, p. 111.

${ }^{9}$ J. Defradas, 1954, p. 13.

${ }_{10}^{10}$ J. M. Mossman, 1997, p. 128.

${ }^{11}$ J. M. Mossman, 1997, p. 129.

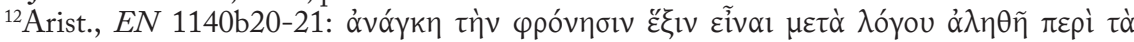

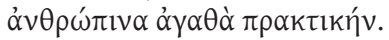


his own defense of animal rationality, De sollertia animalium, Plutarch allows his interlocutor Autobulus to suggest that we should consider animal intellect to be less acute than that of humans rather than claiming that animals are devoid of intellect and practical wisdom altogether ${ }^{13}$.

Shortly after the anecdote of the vain mule, Solon jokingly establishes Aesop's credentials as an expert on animals by calling him "clever at

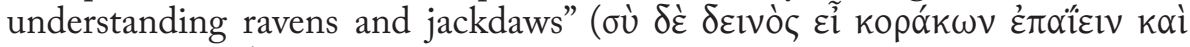

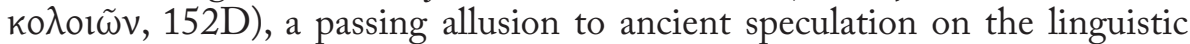
capacities of birds. In Stoic theory, meaningful language was denied to

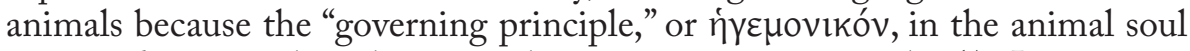
remained irrational so that animal utterances are meaningless ${ }^{14}$. In contrast,

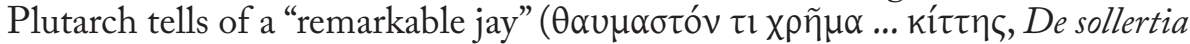
animalium 973C) that meditated upon the sounds of a trumpet that it had heard and repeated only certain of its notes in its own song, suggesting that the self-taught bird possessed more reason than would have been evident in one that had learned from others ${ }^{15}$.

In the next anecdote involving animals, Anacharsis, one of the Seven Wise Men, chastises Aesop for supposing that a home is mere mortar and wood, when even an anthill or a bird's nest can be a happy home if the beasts

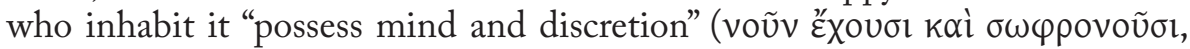
$155 \mathrm{C}$ ). Ants and some bird species figure prominently in ancient literature as animals endowed with impressive intellectual capacities. In his article "Some Stock Illustrations of Animal Intelligence in Greek Psychology," Sherwood Dickerman observed that in classical sources, "four animals appear with a regularity so great as to challenge attention-the ant, the bee, the spider, the swallow (now and then the birds in general)"16. Plutarch (De sollertia animalium $967 \mathrm{E})$ maintains that the behavior of ants suggests that they have the classical virtues of courage, prudence, practical wisdom ( $\varphi \rho \circ v \eta ́ \sigma \varepsilon \omega \varsigma)$ and justice. Here Anacharsis reiterates that claim.

The final allusion to human-animal relations preceding the dolphin anecdotes has been variously interpreted. At 159B-C, Solon laments the fact that the diet of humans by necessity entails injustice because it involves the ingestion of other living things, be they plant or animal, and, perhaps with a nod to Phaedo 66b, he asserts that the need for food weighs down the human soul and renders it gross and impure. G. J. D. Aalders remarks of this lament, "Solon's ideas about the soul and the desirability of restricting one's diet to a minimum (158bff.) can hardly stem from the historical Solon and are not even found in Plutarch's Life of Solon" ${ }^{17}$. Yet if Solon's comments are viewed

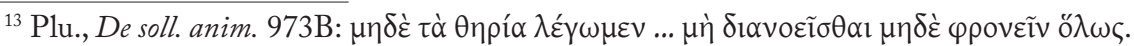

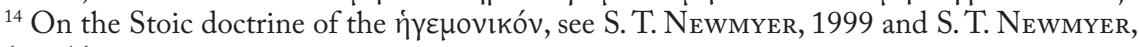
2006, p. 46.

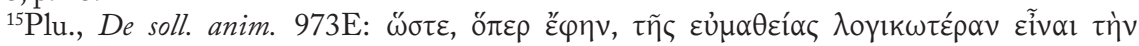

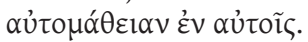

${ }_{16}^{16}$ S. O. Dickerman, 1911, p. 123.

${ }^{17}$ G. J. D. Aalders, 1977, p. 29. 
in the context of Plutarch's theme of human-animal relations developed in the Convivium, his reservations concerning human injustice toward animals seem less problematic, especially if one recalls strikingly similar pronouncements in De esu carnium, Plutarch's argument for vegetarianism, wherein he claims (994E) that animals at the point of slaughter, whose remarkable intelligence

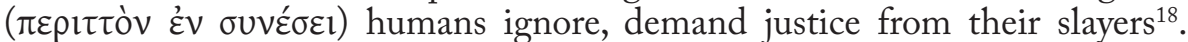
Already in 1893, Georg Hauck had noted the similarity in Plutarch's argumentation here in the Convivium to those passages from his Gryllus and De sollertia animalium where he argues for rationality in animals, a connection which Aalders does not note ${ }^{19}$.

Whether Solon's scruples here are his own or reflect Plutarch's views as stated in the animal treatises, it is noteworthy that the anecdotes of Arion's rescue by dolphins and of the recovery of Hesiod's body by dolphins follow closely upon Solon's expression of concern that human behavior toward other species might have ethical ramifications. Most scholars have judged the dolphin anecdotes to be fundamental to some overarching theme in the Convivium, although the animals have regularly been viewed as instruments rather than as actors in the drama. Defradas, for example, sees the dolphins as agents of justice carrying out the will of the gods on earth ${ }^{20}$, a view which indeed finds textual support both in Arion's conclusion (161F) that his rescue illustrates how god watches over all deeds on land and sea and in Anacharsis' observation concerning the recovery of Hesiod's body (163E-F) that god uses every creature as his instrument (ópyovov, 163E).

Even Luc van der Stockt, who displays greater affection for Plutarch's dolphins as animals than do other scholars, concluded that the animals are "part of a world in which god, man and animals take care of each other" ${ }^{21}$. In van der Stockt's understanding of Plutarch's dolphin anecdotes, god governs the cosmos in such a way that animals serve to unite god and man, and are symbolic of god's sympathy for the universe. Here too, the animals are viewed instrumentally. It can be argued, however, that Plutarch's dolphins are more than passive tools of divine will, and that the dolphin anecdotes form the culmination to the human-animal theme in the Convivium: having raised the possibility, in Solon's comments, that humans might have obligations to act justly toward animals, Plutarch now raises the possibility that some animals may be moved to act justly toward humans, who thereby benefit from actions which, if performed by humans, might be considered instances of $\varphi \imath \lambda \alpha v \theta \rho \omega \pi i$.

In his study of Plutarchan $\varphi \imath \lambda \alpha v \theta \rho \omega \pi i$, Rudolf Hirzel argued that Plutarch understood that term in several senses, ranging from the conviviality of a dinner party, to guest-friendship, to ordinary politeness, to a belief in a

\footnotetext{
${ }^{18}$ On the concept of justice toward animals, see S. T. Newmyer, 1992 and S. T. Newmyer, 2006, pp. 48-65.

${ }^{19}$ G. Hauck, 1893, p. 48.

${ }^{20}$ J. Defradas, 1954, p. 14.

${ }^{21}$ L. VAn der Stockt, 2005, p. 19.
} 
connection between man and man in which one is benefactor to the other ${ }^{22} \mathrm{He}$ points out Plutarch's conviction, influenced by Pythagoras and given voice at De sollertia animalium $959 \mathrm{~F}^{23}$, that kindness to animals inspires $\varphi \imath \lambda \alpha v \theta \rho \omega \pi i$ í toward fellow-humans. He does not suggest that Plutarch believed that a human might practice tò $\varphi \imath \lambda \alpha ́ v \theta \rho \omega \pi$ ov toward animals, much less that animals might be so inclined toward humans. Yet it is the possibility of this ethical relationship that especially distinguishes Plutarch's accounts of dolphin behaviors from the others.

Classicists are familiar with Herodotus' charming account of the rescue of the poet Arion (I.23-24), and may know the versions of Pliny (NH IX. 28) and the post-Plutarchan Aelian (NA XII. 45). In Plutarch's retelling of the tale, two narrative details are added which are absent from earlier versions: the rescue is effected in Plutarch by more than one animal working as a team, and this teamwork inspires human witnesses to suspect ethical motivations in the animals' actions. Pliny (NH IX. 24) calls the dolphin "an animal friendly to man" (bomini ... amicum animal), but he does not ascribe any motivation to the animal's behavior. Similarly, in Herodotus, Arion is rescued by one animal whose motivations are not specified.

In Plutarch's account of the rescue, Gorgus, brother of Periander, tyrant of Corinth who hosts the convivium and at whose court the tale of Arion was set in Herodotus as well, reports witnessing a group of dolphins bearing ashore a man whom the onlookers recognized as the famous Arion (161A). The singer recounted that at the moment when he was about to drown, dolphins

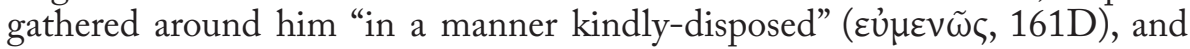
passed him on to one another, "relieving each other as if this were a duty

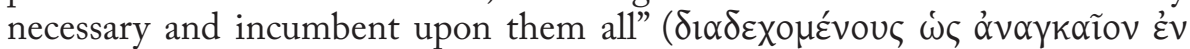

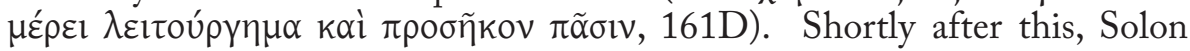
relates that the body of the drowned poet Hesiod was recovered by dolphins who acted, in his view, in a "kindred and human-loving manner" (oikzí $\omega \varsigma$

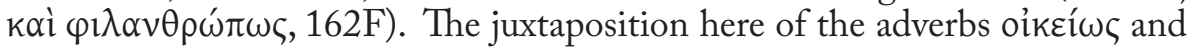
$\varphi \imath \lambda \alpha v \theta \rho \omega ́ \pi \omega \varsigma$ offers critical insight into Plutarch's view of animal intellect and behavior toward human beings, including instances of what might be termed "animal $\varphi \imath \lambda \alpha v \theta \rho \omega \pi i ́ \alpha$ ".

In Stoic ethical theory,oik $\varepsilon^{\prime} \omega \sigma \mathrm{l} \zeta$ was the recognition of kinship, attachment or belonging that one group naturally feels to another that it senses to be akin to itself ${ }^{24}$. Humans experience this toward other humans, and animals toward

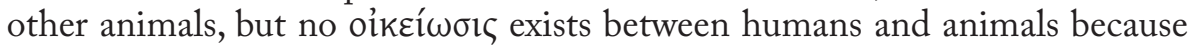
animals are fundamentally unlike humans, being, in Stoic teaching, forever irrational $^{25}$. At De finibus III. 67, Cicero states that the natural consequence of

\footnotetext{
${ }^{22}$ R. Hirzel, 1912, p. 24.

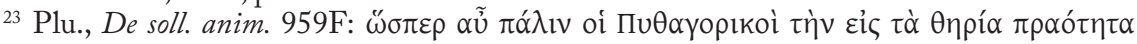

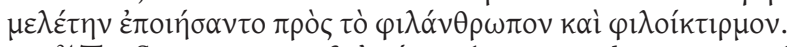

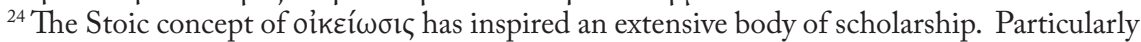
illuminating are C. O. Brink, 1955-1956; G. Striker, 1983; and G. Reydams-Schils, 2003.

${ }^{25}$ Cicero, Off. I. 50, offers the classic formulation of the Stoic position on the lack of
} 
this lack of natural kinship, in the view of the Stoics, was that humans could have no bonds of justice with animals: sed quomodo hominum inter homines esse vincula putant, sic homini nibil iuris cum bestiis.

In De sollertia animalium, Plutarch argued, against the Stoics, that all animals in fact partake of reason to some degree ${ }^{26}$. In Plutarch's view, rationality in animal species differs quantitatively rather than qualitatively from rationality in human beings ${ }^{27}$. Consequently animals must be judged akin (oikkĩol) to human beings after all. Not only are they therefore owed justice, but Plutarch's

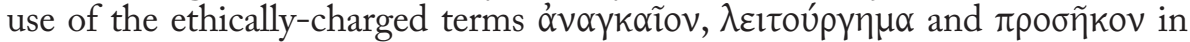
his account of the rescue of Arion in the Convivium (161D) suggests that he considered them to be capable of disinterested and intentional aiding actions that had moral overtones ${ }^{28}$. At De sollertia animalium $984 \mathrm{D}$, one speaker asserts that the dolphin, alone of animals, practices the ideal of the philosophers:

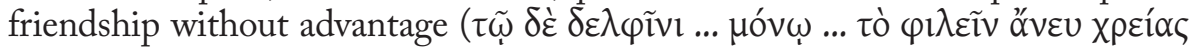

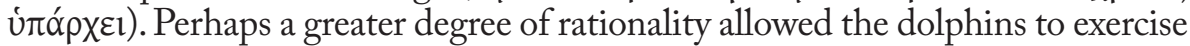
that friendship in a "kindred and human-loving manner" in rescuing Arion and recovering the body of Hesiod, and perhaps too it was a recognition that dolphins were "kindred" (oikeĩol) that led to the unwritten law to which Solon alludes (163A), that no human might harm or hunt them.

While the animal theme traceable in the Convivium is overshadowed by the debate on the form of government proper to human societies and on the role of god in human life, the ideas advanced concerning animals in this dialogue are, as the present study has endeavored to show, entirely in keeping with Plutarch's views as these are set forth at length in his animal treatises. The theme of just and "human-loving" behavior in animals who are hinted to possess, at least to a degree, some of the better intellectual and ethical qualities of human beings adds an intriguing counterpoint to a dialogue devoted to rational discourse on high-minded themes carried on by the Sages of Greece.

\section{WORKS CITED}

\section{Aalders, G. J. D., "Political Thought in Plutarch's Convivium Septum [sic] Sapientium", Mnemosyne, 30 (1977) 28-39.}

\footnotetext{
kinship between humans and irrational animals: Sed quae naturae principia sint communitatis et societatis humanae repetendum videtur altius; est enim primum, quod cernitur in universi generis humani societate. Eius autem vinculum est ratio et oratio, quae docendo, discendo, communicando, disceptando, iudicando conciliat inter se homines coniungitque naturali quadam societate; neque ulla re longius absumus a natura ferarum, in quibus inesse fortitudinem saepe dicimus, ut in equis, in leonibus, iustitiam aequitatem, bonitatem non dicimus; sunt enim rationis et orationis expertes.

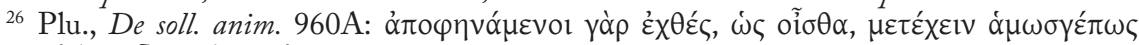

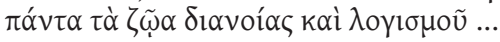

${ }^{27}$ On Plutarch's doctrine of quantitative differences in rationality between species, see $\mathrm{S}$. Newmyer, 2006, p. 40, which provides citations from Plutarch's animal treatises.

${ }^{28}$ For a detailed discussion of Plutarch's ideas on altruistic, cooperative and philanthropic behaviors in non-human animals, see S. Newmyer, 2006, pp. 76-84.
} 


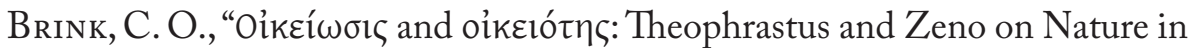
Moral Theory”, Phronesis, 1 (1955-1956) 123-45.

Defradas, J., Plutarque: Le banquet des sept sages (Texte et traduction avec une introduction et des notes), Paris, 1954.

Dickerman, S. O., "Some Stock Illustrations of Animal Intelligence in Greek Psychology”, TAPhA, 42 (1911) 123-30.

Harrison, G. W. M., "Problems with the Genre of Problems: Plutarch's Literary Innovations", CPh, 95 (2000) 193-99.

Hauck, G., Plutarch von Chaeronea, der Verfasser des Gastmahls der 7 Weisen, Burghausen, 1893.

Hirzel, R., Plutarch, Leipzig, 1912.

Mossman, J. M., "Plutarch's Dinner of the Seven Wise Men and Its Place in Symposion Literature", in J. M. Mossman, Plutarch and His Intellectual World: Essays on Plutarch, London, 1997, pp. 119-40.

Newmyer, S. T., "Plutarch on Justice toward Animals: Ancient Insights on a Modern Debate", in Scholia: Natal Studies in Classical Antiquity, n. s. 1 (1992) 38-54.

"Speaking of Beasts: The Stoics and Plutarch on Animal Reason and the Modern Case against Animals", QUCC, n. s. 63 (1999) 99-110. Animals, Rights and Reason in Plutarch and Modern Ethics, Oxford, 2006.

Reydams-Schils, G., "Human Bonding and Oikeiōis in Roman Stoicism", OSAPh, 22 (2003) 221-51.

Shelton, J.-A., "Beastly Spectacles in the Ancient Mediterranean World", in L. Kalof (ed.), A Cultural History of Animals in Antiquity, Oxford and New York, 2007, pp. 97-126.

Sorabji, R., Animal Minds and Human Morals: The Origins of the Western Debate, Ithaca, NY, 1993.

Steiner, G., Anthropocentrism and Its Discontents: The Moral Status of Animals in Antiquity, Pittsburgh, 2005.

Striker, G., "The Role of Oikeiôsis in Stoic Ethics", OSAPh, 1 (1983) 14567.

VAn der Stockt, L.,"Plutarch and Dolphins: Love Is All You Need", in J. Boulogne (ed.), Les grecs de l'antiquité et les animaux: le cas remarquable de Plutarque, Lille, 2005, pp. 13-21.

Wilamowitz-Moellendorff, U. Von, "Zu Plutarchs Gastmahl der Sieben Weisen”, Hermes, 25 (1890) 196-227. 